\section{Filozoficzne świadectwo Zagłady Doroty Głowackiej. Znaczenie współ-pamięci i wyobraźni relacyjnej w refleksji nad Zagładą}

Katarzyna Liszka
$\mathbf{N}$ a książkę Po tamtej stronie: świadectwo, afekt, wyobraźnia składa się dziewięć rozdziałów o zróżnicowanej tematyce. Dorota Głowacka w dialogu i polemice ze współczesnymi myślicielami, takimi jak m.in. Emmanuel Levinas, Hannah Arendt, Jean-Luc Nancy, Julia Kristeva, Chantal Mouffe, Michal Rothberg, analizuje literaturę, film, dyskurs publiczny i polityczny w odniesieniu do Zagłady i jej dalekosiężnych konsekwencji.

Tytułowe Po tamtej stronie odnosi się do doświadczenia autobiograficznego autorki, ale też metaforycznie sygnalizuje zarówno perspektywę, jak i kierunek teoretycznego namysłu. Być „po tamtej stronie” to przede wszystkim ryzyko znalezienia się po niewłaściwej stronie. „Remember: once you cross the Atlantic, you are always on the wrong side"1 - fragment listu przyjaciela nadesłanego w pierwszym roku emigracji autorki z Polski do Kanady, komentuje ona następująco: „Jak można się samookreślić, gdy każde słowo, którym się nazywam, dzieli

1 Recenzja książki: D. Głowacka Po tamtej stronie: świadectwo, afekt, wyobraźnia, Wydawnictwo IBL PAN, Warszawa 2016, s. 17.
Katarzyna Liszka adiunkt w Katedrze Studiów Żydowskich Uniwersytetu Wrocławskiego. Ukończyła kulturoznawstwo, filozofię i Studium Języków i Kultury Żydowskiej na UWr. Zajmuje się problematyką Zagłady, współczesną filozofią, etyką, w tym filozofią żydowską. Autorka monografii Etyka i pamięć o Zagładzie, współredaktorka Beauty, Responsibility, and Power: Ethical and Political Consequences of Pragmatist Aesthetics i Między rozumieniem a porozumieniem. Eseje o demokracji niekonsensualnej. 
nieustannie podwójny łącznik: I am Polish-Jewish-Canadian?”2 . Owe „potrójne wyobcowanie i potrójna przynależność"3 przekładają się na złożone spojrzenie badawcze, dzięki któremu autorka analizuje fenomeny i koncepcje z różnych perspektyw jednocześnie, zachowując wyczulenie zarówno na różnice, jak i na nieoczywiste punkty zbieżne. Ponadto "po tamtej stronie" sygnalizuje obszar teoretycznego namysłu nad relacyjnością doświadczenia, pamięci i wyobraźni (własne-obce, ja-inny, wspólnota i bycie pomiędzy), oraz potrzebę wypracowania odnośnych kategorii w humanistyce, a w węższym ujęciu w refleksji odnoszącej się do Zagłady.

Z mojej perspektywy w Po tamtej stronie Dorota Głowacka konsekwentnie realizuje pewną strategię filozoficzną i etyczną, którą postaram się odsłonić. Niniejszą pracę można scharakteryzować jednocześnie jako studium z zakresu badań/refleksji nad Zagładą, które prowadzi do analizy współczesności, oraz jako studium z zakresu humanistyki, dla którego istotną cezurę stanowi Zagłada. Konstrukcyjną osią książki jest więc przechodzenie od refleksji nad Zagładą do filozoficznego namysłu nad współczesnością, przy czym refleksja etyczna jest tu wiodąca.

Pamięć o Zagładzie stanowi jedno ze źródeł moralnej i prawnej normatywności kultury europejskiej, i nie tylko, biorąc pod uwagę tendencje globalizacyjne oraz przekształcenie pamięci o Zagładzie w idiom praw człowieka, na co zwracają uwagę Natan Sznaider i Daniel Levy w Holocaust and Memory in the Global Age $e^{4}$. Śledzenie przez autorkę dynamiki zmieniających się ram pamięci o Zagładzie, a także ram teoretycznych rozumienia Zagłady, jest w tym kontekście zadaniem o sporej stawce etycznej, a także politycznej. Tego rodzaju krytyczny namysł mierzy się bowiem jednocześnie, jak wskazują redaktorzy Probing the Ethics of Holocaust Culture (2016), ze znaczącym przewartościowaniem rozumienia związków między moralnością a Zagładą, które wyraża się m.in. w tym, że konsensus z lat 9o. co do przekonania o „centralności Zagłady dla zapobiegania przyszłym katastrofom praw człowieka"5, już nie istnieje.

2 Tamże, s. 19.

3 Tamże, s. 22.

4 D. Levy, N. Sznaider Holocaust and Memory in the Global Age, trans. A. Oksiloff, Temple University Press, Philadelphia 2006.

5 W. Kansteiner, T. Presner Introduction. The Field of Holocaust Studies and the Emergence of Global Holocaust Culture, w: Probing the Ethics of Holocaust Culture, ed. by C. Fogu, W. Kansteiner, T. Presner,Harvard University Press, Cambridge, MA 2016, s. 2. 
Książka Doroty Głowackiej może być odczytywana na wielu poziomach, gdyż autorka analizuje napięcia - psychologiczne, kulturowe, historyczne i egzystencjalne. Jednakże śledzenie konturów napięć i różnicy doświadczeń nie służy jedynie konstatacji: tak jest. Odczytuję refleksję Doroty Głowackiej - zwracając szczególną uwagę na kategorie współ-pamięci, wyobraźni relacyjnej i afektywnych modalności demokracji - jako swoistą propozycję budowania teoretycznej przestrzeni namysłu dla spotkania, być może nawet jakiejś formy integracji doświadczeń i perspektyw rozłączonych, odseparowanych. Dla ukazania powyższej tezy odniosę się do tych fragmentów książki, które dotyczą podziałów pamięciowych, w tym relacji między polską a żydowską pamięcią Zagłady, genderowych uwarunkowań pamięci o Zagładzie oraz zestawienia epistemologii eurocentrycznej z epistemologią ludności rdzennej w dyskursie praw człowieka i studiach nad Zagładą.

W rozdziale 4. Polska wspót-pamięć i dylematy przekładu w wycinkach $z$ Shoah Claude'a Lanzmanna Dorota Głowacka deklaruje:

Stawiam hipotezę, że przed kamerą Lanzmanna zachodzi momentami szczególna forma niesienia świadectwa, którą określam mianem „współ-pamięci". Umyka ona często świadomości uczestników rozmów i jest cenzurowana przez reżysera, który, jak dowiadujemy się, oglądając wycinki, wykluczył ją z ostatecznej wersji filmu. ${ }^{6}$

Analiza Shoah Lanzmanna i wycinków udostępnionych przez United States Holocaust Memorial Museum w Waszyntonie pozawala według autorki wysunąć kilka wniosków: po pierwsze, zakwestionować powszechnie przyjęte interpretacje, że film odsłania jedynie konflikt między polską a żydowską pamięcią Zagłady"', po drugie, odsłonić praktyki „kolonizatorskie” Claude’a Lanzmanna w stosunku do polskich rozmówców, języka polskiego, który zajmuje w językowej hierarchii filmu ostatnie miejsce. Po trzecie, na tle ważnej dyskusji rewidującej Hilbergowską triadę sprawcy-ofiary-świadkowie, a w szczególności oferującej rozbiór kategorii polskiego „świadka” (bystander-witness) $)^{8}$, powyższa analiza otwiera ważne możliwości interpretacyjne. Głowacka podejmuje próbę usłyszenia głosu polskiego świadka Zagłady

D. Głowacka Po tamtej stronie, s. 100.

7 Tamże.

8 J.T. Gross Sprawcy, ofiary i inni, „Zagłada Żydów” 2014 nr 10, t. 2: Materiały, s. 885-888. 
(nawet jeśli jest to świadectwo negatywne9), jak i teoretyczny namysł nad możliwością takiego świadectwa. Kategoria „współ-pamięci” osadzona teoretycznie w refleksji Jean-Luc Nancy'ego na temat wspólnoty rozdzielonej oraz współ-bycia wskazuje na możliwość budowania ram pamięci, które nie przylegają do dominujących, wspólnotowych (etnicznych bądź narodowych) skryptów i podziałów. Wskazując m.in. na rozmowy w języku polskim Szymona Srebnika z mieszkańcami Chełmna, podkreśla, że współ-pamięć nie oznacza pamiętania tego samego. Jest to pamięć z własnego miejsca, gdzie „pamiętający pochylają się ku sobie, choć pamiętają przeszłość «inaczej»"10.

Namysł nad współ-pamięcią koresponduje z pogłębioną analizą dotyczącą modalności afektywnych demokracji - strachu i miłości, analizą, która wychodzi od polskich zbrodni wobec Żydów, popełnionych w czasie II wojny światowej i po niej, przy czym podstawowym odniesieniem tekstualnym pozostaje tu Strach ${ }^{11}$ Jana Tomasza Grossa. W powojennej Polsce strach, jak pokazuje Głowacka, stanowi „afekt antydemokratyczny, powodujący, że pokojowe współistnienie etnicznych Polaków i polskich Żydów staje się niemożliwe. Strach okazał się więc afektywnym wyrazem bezkompromisowej nietolerancji wobec inności, która stanowi fantazmatyczne zagrożenie dla wspólnoty narodowej"12. Miłość jako biegunowo odmienny afekt wydaje się z kolei siłą gruntującą demokrację. Oryginalność refleksji Głowackiej polega na wskazaniu relacji między miłością a strachem jako afektywnymi modalnościami demokracji, a także na ukazaniu ambiwalencji obu tych afektów. Rozwijając myśl Julii Kristevej podkreśla, że miłość jako otwarcie na inność budzi lęk, z kolei lęk może prowadzić do dostrzeżenia inności w sobie, hamując agresywne projekcje na Innego. „Tak jak lęk przenika sferę publiczną, jako zarówno zagrożenie, jak i zawsze obecny, konstytutywny warunek tworzenia się wspólnoty, tak i miłość jest zarówno siłą mogącą potencjalnie rozbić wspólnotę, jak i tym, co nas ku sobie skłania, choć nie ma wątpliwości, że są to afekty biegunowo odmienne"13. Powiązanie współ-pamięci i demokracji

9 "Określam ich świadectwo mianem «świadectwa negatywnego», które, mimo że jest wykrzywioną wersją historii, odsłania skomplikowane pokłady i zasupłania polskiej pamięci o Zagładzie". D. Głowacka Po tamtej stronie, s. 109.

Tamże, s. 123.

J.T. Gross Strach. Antysemityzm w Polsce tuż po wojnie. Historia moralnej zapaści, Znak, Warszawa 2008.

D. Głowacka Po tamtej stronie, s. 226.

Tamże, s. 243. 
agonistycznej opartej na modalnościach afektywnych strachu i miłości wydają się krokiem w kierunku stworzenia etyczno-politycznej wizji, o której pisze Głowacka we wprowadzeniu:

Żywię więc nadzieję, że w miejsce negatywnego schematu wykluczających się nawzajem polskich i żydowskich narracji martyrologicznych, z których każda rości sobie prawa do wyjątkowości, wyłoni się kiedyś etyczno-polityczna wizja wzajemnie przeplatających się dziejów i sposobów samookreślenia oraz wzajemnie stwarzających się tożsamości. ${ }^{14}$

Teoretyczne interwencje w zastane ramy pamięci, reprezentacji i rozumienia Zagłady nie dotyczą w Po tamtej stronie jedynie relacji polsko-żydowskich i ich reprezentacji. W rozdziale zatytułowanym „Nigdy więcej!" Pamięć o ludobójstwie ludności rdzennej a pamięć o Zagładzie (ze szczególnym uwzględnieniem Kanady) Dorota Głowacka porusza kwestię walki ludności rdzennej USA i Kanady o uznanie za ludobójstwo zbrodni dokonanych przez kolonizatorów, które prowadziły do uśmiercenia 95 procent ludności rdzennej. Analizuje szerokie odwołania do toposów Zagłady przez myślicieli i aktywistów ludności rdzennej. Zgłasza postulat dekolonizacji studiów nad Zagładą jako nowego otwarcia:

Proponuję, abyśmy w podobny sposób rozpatrzyli wykorzystywanie języka Zagłady przez rdzennych myślicieli i działaczy: nie jako obrazoburczy przykład „olimpiady cierpienia”,lecz jako przypadek kognitywnej niesymetryczności powodujący, że zarówno rdzenni myśliciele, jak i osoby, które przetrwały szkoły dla Indian, zmuszone są negocjować swoje roszczenia co do sprawiedliwości historycznej i społecznej przez pryzmat „białego systemu poznawczego”. Jakie białe plamy odsłoniłyby się w nagromadzonej przez nas wiedzy na temat genezy Zagłady, mechanizmów masowych mordów oraz doświadczeń poszczególnych ofiar, gdybyśmy tę wiedzę przefiltrowali przez nieeurocentryczne systemy pojmowania rzeczywistości?

Postulat dekolonizacji studiów nad Zagładą oznacza otwarcie pola badawczego na perspektywę porównawczą, która niewątpliwie przekształci ramy pamięci i wiedzy o Zagładzie. 
W rozdziale Płeć i Zagłada: wyobraźnia relacyjna i zapomniane zautki Głowacka zwraca uwagę na funkcjonowanie społecznych ram pamięci o Zagładzie w odniesieniu do głosu kobiet-świadków oraz ich doświadczenia. Powołując się na klasyczne już prace z zakresu genderowych studiów nad Zagładą, opisuje przykłady milczenia, wykluczenia i pominięć - m.in.,wycięcie”głosu Ruth Elias z Shoah Lanzmanna, oskarżenia, wykluczenie i milczenie (Władysława Szpilmana, a także filmowej reprezentacji losów pianisty autorstwa Stevena Spielberga) na temat Wiery Gran. Analiza Doroty Głowackiej koncentruje się na nawykach percepcyjnych i epistemologicznych, które kształtują obraz tego, co widzimy i wiemy. Zdaniem Doroty Głowackiej pamięć o Zagładzie wymaga systematycznej korekty z punktu widzenia feminizmu i studiów genderowych, które uczynią słyszalnym i widzialnym kobiece doświadczenie Zagłady. Ćwiczenia z patrzenia, rozumienia i pamiętania, jak przekonuje Głowacka, potrzebują pracy wyobraźni, która to praca staje się imperatywem etycznym. Głowacka proponuje wprowadzenie pojęcia „wyobraźnia relacyjna”:

Wyobraźnia relacyjna, czy też „wyobraźnia-z-innymi”, poprzedza więc pojęcie wyobraźni rozumianej jako najwyższy wyraz osobistej wolności. Jest ona niezbędna, abyśmy byli w stanie uzmysłowić sobie, czym jest cierpienie drugiego człowieka, oraz przyjąć, że jego prawo do bycia wolnym od cierpienia spoczywa również na naszych barkach. ${ }^{15}$

Wyobraźnia relacyjna ma wpływ na to, jak pamiętamy o przeszłości. Pojęcie to wskazuje na odpowiedzialność jednostek za to, jak patrzą, słyszą, rozumieją, pamiętają. W przypadku pamięci o Zagładzie „nawykowa ślepota” szczególnie wtedy, gdy powtarza gest sprawców polegający na odzieraniu z człowieczeństwa ofiar, jest groźna w znaczeniu etycznym. Nieludzkie traktowanie, traktowanie człowieka jak nie-człowieka jest bowiem powiązane z nawykami percepcji, widzenia bądź niedostrzegania zarówno człowieczeństwa, jak i form upokorzenia, które usiłują owe człowieczeństwo odebrać.

Współ-pamięć, wyobraźnia relacyjna, demokracja oparta na dynamice strachu i miłości, postulat dekolonizacji studiów nad Zagładą stanowią nowe otwarcie dla filozoficznej refleksji nad Zagładą, zaś mocą przykładów i analiz konkretnych fenomenów, konfliktów i tekstów zyskujemy cenne aplikacje owych pojęć. 
$\mathrm{Na}$ koniec przywołam fragment rozdziału piątego Hannah Arendt i Sarah Kofman: filozofia "po kobiecemu" wobec Zagtady, który w moim przekonaniu podpowiada ważną sugestię interpretacyjną dla lektury Po tamtej stronie:

obie myślicielki skutecznie przebijają się przez filozoficzne wały obrony, które eliminują kobiecość, żydowskość oraz realia historyczne. W ten sposób obie podważają „standardowe narracje filozoficzne”. [...] W tym wielokrotnym zetknięciu się refleksji nad Zagładą, kondycją żydowską oraz kwestią kobiecości dzieła Kofman i Arendt możemy odczytać jako filozoficzne świadectwo Zagłady ze specyficznie feministycznej perspektywy. ${ }^{16}$

Sądzę, że w podobny sposób możemy odczytać Po tamtej stronie Doroty Głowackiej, jako filozoficzne świadectwo Zagłady, akt pamięci, który zapisuje się na marginesach dzieł współczesnej humanistyki, w którym podobnie, jak w przypadku Kofman i Arendt, refleksja nad Zagładą, tożsamością i głosem stanowi zarazem tło, motywację, jak i kierunek namysłu.

\section{Abstract}

\section{Katarzyna Liszka}

UNIVERSITY OF WROCŁAW

Dorota Głowacka's Philosophical Testimony of the Holocaust: The Significance of the Ethics of Co-Memory and Relational Imagination in Holocaust Studies

Review: Dorota Głowacka, Po tamtej stronie:świadectwo, afekt, wyobraźnia [On the Other Side: Testimony, Affect, Imagination] (Warsaw: Wydawnictwo IBL PAN, 2016), 295 pp.

\section{Keywords}

Holocaust, ethics, co-memory, relational imagination, affect 